\title{
Effect of Improved Management Practices on Soil Organic Carbon Sequestration in Wheat-maize Double Cropping System in North China
}

\author{
Liqun Zhu ${ }^{1}$, Minfang Yang ${ }^{2} \&$ Changqing Chen ${ }^{1}$ \\ ${ }^{1}$ College of Agriculture, Nanjing Agricultural University, Nanjing 210095, China \\ ${ }^{2}$ College of Resources and Environmental Science, Nanjing Agricultural University, Nanjing, China \\ Correspondence: Liqun Zhu, College of Agriculture, Nanjing Agricultural University, Nanjing 210095, China. \\ Tel: 86-25-8439-5338. E-mail: zhulq@njau.edu.cn
}

Received: May 24, 2012 Accepted: June 20, 2012 Online Published: July 26, 2012

doi:10.5539/jas.v4n9p114 URL: http://dx.doi.org/10.5539/jas.v4n9p114

\begin{abstract}
Carbon sequestration in cropland soils which could be achieved through improved management practices (IPMs) represents an important opportunity to offset a portion of greenhouse gas emissions. North China is the main wheat and maize production region where many IMPs have been widely used during the last several decades, but the effect size and duration of IMPs on soil organic carbon (SOC) sequestration in wheat-maize double cropping system in this region is scarcely studied. In this study, a meta-analysis was conducted to compare the effect size and duration of four IMPs on SOC sequestration in wheat-maize double cropping system in north China. A total of 29 long-term experiments, consisting of 119 paired treatments were compiled in this analysis. The results indicated that the four IMPs of organic manure application (OM), organic manure combined with chemical fertilizer application (MF), straw return (SR) and reduced or no tillage (RNT) all had significant effects on SOC sequestration in the study area. On average, the IMPs of OM, MF, SR and RNT enhanced SOC density by 260 , 328,278 and $134 \mathrm{~kg} \mathrm{ha}^{-1} \mathrm{yr}^{-1}$, respectively. The effect duration of OM, MF, SR and RNT on SOC sequestration were about 48, 26, 22 and 18 years, respectively. Accumulation enhancements of SOC for OM, MF, SR and RNT over SOC sequestration period were about $34.7 \%, 36.1 \%, 22.0 \%$ and $12.7 \%$, respectively. OM and MF could be the appropriate practices on SOC sequestration in wheat-maize double cropping system in the research area.
\end{abstract}

Keywords: improved management practice, soil organic carbon, carbon sequestration, wheat-maize double cropping system, North China

\section{Introduction}

The concentration of $\mathrm{CO}_{2}$ in the atmosphere has increased from $280 \mu \mathrm{mol} \mathrm{mol}{ }^{-1}$ before industry revolution to $379 \mu \mathrm{mol} \mathrm{mol}^{-1}$ in 2005, and it would be increasing by $1.9 \mu \mathrm{mol} \mathrm{mol}^{-1}$ per year (IPCC, 2007). Great attention has been paid to carbon (C) sequestration to reduce the $\mathrm{CO}_{2}$ concentration for mitigating global climate change since last late century. Carbon sequestration in cropland soils is an important way to meet emission reduction targets (Morari, Lugato, Berti, \& Giardini, 2006), which could be achieved through improved management practices (IMPs), such as reduced or no tillage, soil application of manure, crop residues recycling, cover and deep-rooting crops (Follett, 1993; Follett, 2001; Lal, 2004; Havlin, Kissel, Maddux, Claassen, \& Long, 1990; Lal, Follett, Kimble, \& Cole, 1999; Uri, 2001). As a global basis, Lal estimated that agricultural soils could potentially sequester $0.4-0.8 \mathrm{Pg} \mathrm{C}_{\mathrm{Cear}}{ }^{-1}$ by adopting IMPs (Lal, 2004), which accounts for about 33.3-100\% of the total potential of $\mathrm{C}$ sequestration in global soils. Although many researchers have studied the effects of the IMPs on $\mathrm{C}$ sequestration in cropland soils through long-term experiments (Morari, et al., 2006; John, Marcus, Ronald, \& James, 2008; Upendra, Zachary, Ermson, Irenus, \& Reddy, 2008; Wang \& Kang, 2009), the results among them were always inconsistent and uncertain varying from significant increase to significant decrease (Alvaro-Fuentes, Lopez, Cantero-Martinez, \& Arrue, 2008; Christopher, Lal \& Mishra, 2009). Moreover, it was unclear whether this inconsistency was caused by environmental, or management factors or by sampling errors and analysis methodology (Luo, Wang, \& Sun, 2010). The results of each research only represented a particular plot site, which could not represent a region. 
Except for the management practices on cropland, $\mathrm{C}$ sequestration in cropland soils was also affected by many other factors, such as climate and soil conditions (Yan, Cao, Liu, \& Tao, 2007; Angers, 1997; Gregorich, Rochette, VandenBygaart, \& Angers, 2000; Hermle, Anken, Leifeld, \& Weisskopf, 2008). Therefore, the effect sizes of a variety of IMPs on soil C sequestration of cropland were significantly different among regions (Smith, 2004a). In order to select appropriate IMPs for a certain region, understanding the effect size and duration of the different IPMs on soil C sequestration of cropland in this region is necessary. The quantitative assessment of the effect size and duration of different IPMs on soil C sequestration in certain region is a very important step. But up to now, only several studies have been undertaken in this aspect. West and Post reported that a change from conventional tillage (CT) to no-till (NT) can sequester about $57 \pm 14 \mathrm{~g} \mathrm{C} \mathrm{m}^{-2} \mathrm{yr}^{-1}$ with duration of 15-20 years based on a global database of long-term agricultural experiments (West \& Post, 2002). In an analysis of 17 long-term tillage experiments in Europe, Smith et al. found that the average increase of soil organic carbon (SOC) with a change from CT to NT was $0.73 \pm 0.39 \% \mathrm{yr}^{-1}$, and that SOC may reach a new equilibrium in approximately 50 to 100 years (Smith, Powlson, Glendining, \& Smith, 1998). Using a coupled remote sensing and process-based ecosystem model, Yan et al. estimated that an annual soil C sequestration of $50 \%$ no-tillage arable lands and 50\% crop residue returning to soils was about $32.5 \mathrm{Tg} \mathrm{C}$ in China, and the effect lasted for only 20-80 years (Yan et al., 2007). Rui and Zhang compared the effect size and duration of several common IMPs on SOC sequestration in paddy field in the Yangtze Delta Plain of Eastern China based on meta analysis, the result showed that crop residue additions and animal manure applications increased SOC by $0.41 \mathrm{Mg} \mathrm{ha}^{-1} \mathrm{yr}^{-1}$ and 0.34 $\mathrm{Mg} \mathrm{ha}{ }^{-1} \mathrm{yr}^{-1}$ on average during the experiment period and only over periods of about 20 and 40 years, respectively (Rui \& Zhang, 2010). No one had estimated the effect size and duration of different IMPs on SOC sequestration in wheat-maize double cropping system in north China.

China is a large agricultural country where wheat and maize are the main grain crops, the total sown area and yield of wheat and maize accounted for about $50.1 \%$ and $52.7 \%$ of all grain crops in China in 2008, respectively (Editorial Board of China Agriculture Yearbook, 2009). North China is the main wheat and maize production region, and wheat-maize double cropping system is the region's most important cropping system (Chen, Wei, \& Yang, 1992; Zhao, Chen, \& Zhang, 2009). The total sown area and yield of wheat and maize in north China accounted for about $42.7 \%$ and $47.0 \%$ of the whole China, respectively in 2008 (Editorial Board of China Agriculture Yearbook, 2009). Considering the issue of national food security, the conditions for agricultural production and planting history in the region, wheat-maize double cropping system would continue to be the most important cropping system in this region in the future (Zhao et al., 2009).

During the past several decades, many IMPs (e.g. straw return, reduced or no tillage, organic manure application and organic manure combined with chemical fertilizer application) have been widely used and promoted, and many long-term field experiments related to SOC sequestration affected by IMPs in wheat-maize double cropping system were also conducted in north China (Wang \& Kang, 2009; Niu et al., 2009; Kong, Zhang, Sun, Huang, \& Chen, 2010; Han, Kong, Zhang, \& Chen, 2010). It is a good opportunity to estimate the effect size and duration of IMPs on SOC sequestration using those research data from previous long-term experiments. Due to the discrepancies of the climate and soil conditions, the IMPs types and the treatment levels among these field experiments, it is still difficult to directly compare the effect size and duration of each IMP on SOC sequestration. Meta analysis refers to a statistical method used to analyze and summarize the collected research data among many individual experiments with an attempt to provide the quantitative average effect to answer the research question. Its advantage is to increase the reliability of conclusions by increasing the sample size, so as to address the research inconsistency of the results (Hechtel \& Juliano, 1997). Therefore, the objectives of this study were to: (1) use meta analysis to quantitatively estimate the effect size and duration of each IMP (e.g. straw return, reduced or no tillage, manure application and fertilizer combined with manure application) on SOC sequestration in wheat-maize double cropping system in north China, (2) determine a most effective practice benefiting for SOC sequestration in wheat-maize double cropping system in north China.

\section{Materials and Methods}

\subsection{Study Area}

The study area is located in north China, including Beijing and Tianjin City, Hebei, Henan, Shandong and Shanxi provinces (Figure. 1), which contains $6.92 \times 10^{5} \mathrm{~km}^{2}$ cropland. This region is Warm Temperate Zone (WTZ) and Semihumid Climate Zone. The seasons are hot and rainy in summer, cold and dry in winter. The annual average temperature is from 5 to $20^{\circ} \mathrm{C}$, and annual precipitation reaches $400-800 \mathrm{~mm}$. North China is the main region of maize and wheat production and important commodity grain base in China, and wheat-maize double cropping system is the region's most important cropping systems. Wheat-maize double cropping system in this region is: 
two crops are sown and harvested one after another in a year. Wheat is sown in the late of autumn after maize is harvested, and harvested in the middle of summer when maize is sown. The sowing and harvesting time is different from place to place according to where the experimental site is located.

\subsection{Date Sources}

Field experiments from the published literature that recorded the response of SOC to changes from the control treatment $(\mathrm{CK})$ to IMP treatments in wheat-maize double cropping system, and were greater than 3 years of period, were used in this study. The data from the published literature included the initial and final content of SOC or SOM in the control (CK) and IMP treatments. Experimental information, including experiments site (Figure 1), period of experiments, soil type and depth, were also considered in this study.

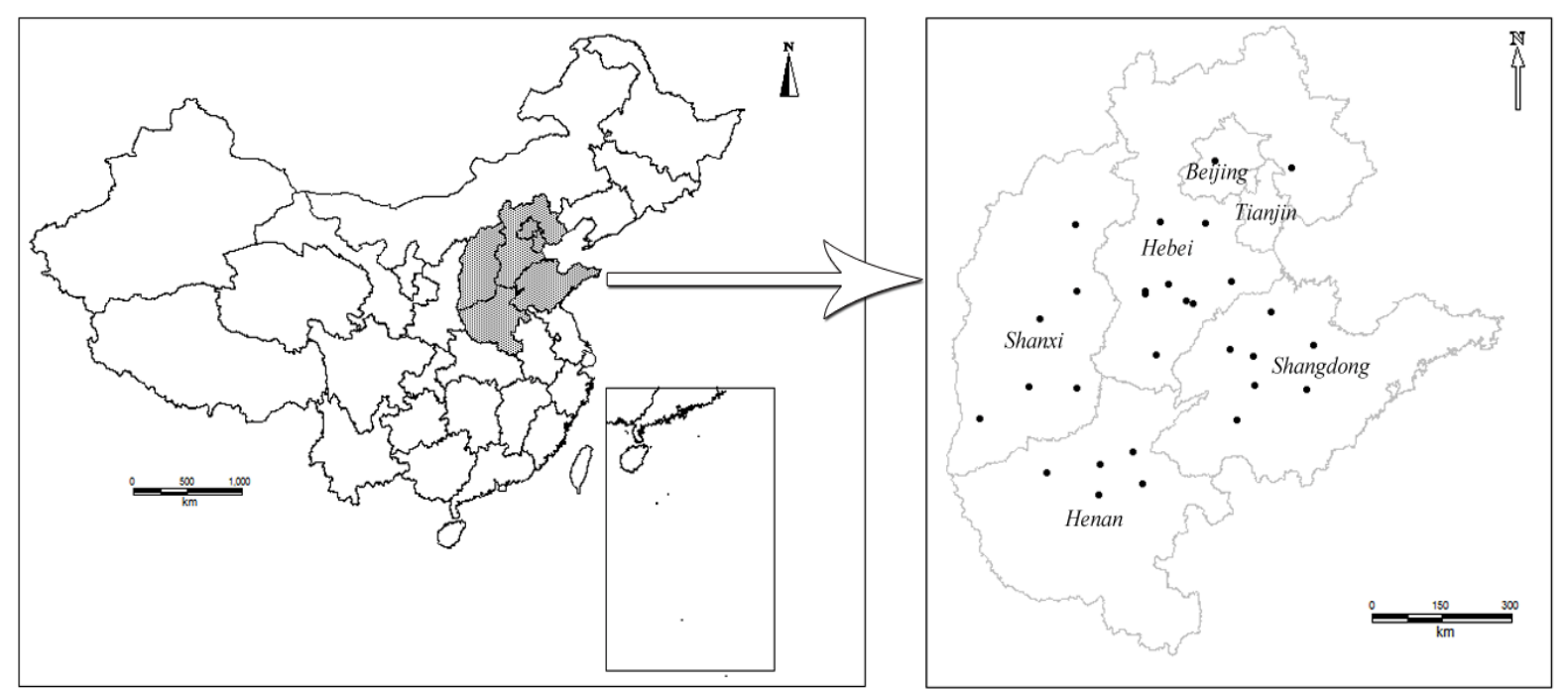

Figure 1. Study area and distribution of experiments site

A total of 29 long-term experiments in north China, consisting of 119 paired treatments were compiled in this analysis (Table 1). The periods of these experiments ranged from 3 years to 25 years with an average of 9.3 years. The mean depth of soil sampling in all experiments was $21.2 \mathrm{~cm}$. The observations of organic manure application (OM), organic manure combined with chemical fertilizer application (MF), straw return (SR) and reduced or no tillage $($ RNT) accounted for $21.8 \%(n=26), 26.9 \%(n=32), 37.0 \%(n=44)$ and $14.3 \%(n=17)$ of the total, respectively.

The data of SOC or soil organic matter (SOM) content were collected from tables or text of all the selected published literature, as well as some data extracted from figures by the graph digitizing software, Getdata v.2.22 (Fedorov, 2006). The SOC content in all experiments of the selected articles was determined using the potassium dichromate method (Nelson \& Sommers, 1982). An index of 0.58 was used in conversion of SOM to SOC content. Because there was no soil bulk density $(B D)$ data in most of the experiments, the following non-linear equation was used to estimate $B D$ (Eq. (1)) (Adams, 1973).

$$
B D=\frac{100}{\left(C_{S O M} / 0.244\right)+\left(\left(100-C_{S O M}\right) / 1.64\right)}
$$

where $B D$ is soil bulk density $\left(\mathrm{g} \mathrm{cm}^{-3}\right), 0.244$ is the bulk density of SOM, 1.64 is the bulk density of soil mineral matter, and $C_{S O M}$ is the content of SOM (\%).The SOC density was calculated as:

$$
D_{S O C}=C_{S O C} \times B D \times H \times 0.1
$$

where $D_{S O C}$ is SOC density $\left(\mathrm{kg} \mathrm{ha}^{-1}\right), C_{S O C}$ is the content of SOC $\left(\mathrm{g} \mathrm{kg}^{-1}\right), H$ is the soil depth (cm). 
Table 1. Long-term field experiments selected from the published references

\begin{tabular}{|c|c|c|c|c|c|c|}
\hline No. & Location & Soil type & IMP & $\begin{array}{c}\text { Period } \\
(\mathrm{yr})\end{array}$ & $\begin{array}{l}\text { Soil } \\
\text { depth } \\
(\mathrm{cm})\end{array}$ & References \\
\hline 1 & Zhengzhou (Henan Province) & Fluvo-aquic soil & $\mathrm{OM}, \mathrm{MF}$ & 3 & 20 & Zhu et al. (1996) \\
\hline 2 & Zibo ( Shandong Province) & Cinnamon soil & $\mathrm{OM}, \mathrm{MF}$ & 3 & 20 & Jin et al. (1983) \\
\hline 3 & Xinji (Hebei Province) & Fluvo-aquic soil & OM,SR, MF & 4 & 20 & Xin et al. (2010) \\
\hline 4 & Fengqiu (Henan Province) & Fluvo-aquic soil & $\mathrm{OM}, \mathrm{MF}$ & 5 & 20 & Qin et al. (1998) \\
\hline 5 & Changge (Henan Province) & Fluvo-aquic soil & $\mathrm{OM}, \mathrm{MF}$ & 7 & 20 & Liu et al. (1993) \\
\hline 6 & Zunhua (Hebei Province) & Fluvo-aquic soil & $\mathrm{SR}, \mathrm{MF}$ & 8 & 20 & Han et al. (2003) \\
\hline 7 & Kaifeng (Henan Province) & Fluvo-aquic soil & $\mathrm{OM}, \mathrm{MF}$ & 10 & 20 & Kou et al. (2000) \\
\hline 8 & Fengqiu (Henan Province) & Fluvo-aquic soil & $\mathrm{OM}$ & 13 & 20 & Meng et al. (2005) \\
\hline 9 & Changping (Beijing) & Fluvo-aquic soil & $\mathrm{SR}, \mathrm{MF}$ & 13 & 20 & Song et al. (2007) \\
\hline 10 & Changping (Beijing) & Fluvo-aquic soil & $\mathrm{SR}, \mathrm{MF}$ & 16 & 20 & Liu et al. (2009) \\
\hline 11 & Fengqiu (Henan Province) & Fluvo-aquic soil & $\mathrm{OM}, \mathrm{MF}$ & 18 & 20 & Gong et al. (2008) \\
\hline 12 & Changping (Beijing) & Fluvo-aquic soil & MF & 19 & 20 & Dong et al. (2010) \\
\hline 13 & Hengshui (Hebei Province) & Fluvo-aquic soil & $\mathrm{OM}, \mathrm{SR}, \mathrm{MF}$ & 25 & 20 & Li et al. (2007) \\
\hline 14 & Quzhou (Hebei Province) & Fluvo-aquic soil & SR & 3 & 30 & Ma et al. (2003) \\
\hline 15 & Taian (Shandong Province) & Brown soil & RNT, SR, & 4 & 20 & Tian et al. (2010) \\
\hline 16 & Shijiazhuang (Hebei Province) & Fluvo-aquic soil & RNT, SR, & 5 & 30 & Li et al. (2006) \\
\hline 17 & Chongzhou (Shandong Province) & Cinnamon soil & $\mathrm{OM}$ & 5 & 20 & Huang (1984) \\
\hline 18 & Luoyang (Henan Province) & Cinnamon soil & RNT, SR & 3 & 20 & Wang et al .(2007) \\
\hline 19 & Nanpi (Hebei Province) & Fluvo-aquic soil & $\mathrm{OM}$ & 6 & 20 & Gu et al. (1992) \\
\hline 20 & Jinan (Shandong Province) & Fluvo-aquic soil & RNT, SR & 6 & 20 & Li et al. (2009) \\
\hline 21 & Shouyang (Shanxi Province) & Cinnamon soil & $\mathrm{OM}, \mathrm{SR}, \mathrm{MF}$ & 7 & 20 & Wang et al. (2000) \\
\hline 22 & Luancheng (Hebei Province) & Fluvo-aquic soil & RNT, SR & 8 & 20 & Han et al. (2010) \\
\hline 23 & $\begin{array}{c}\text { Changzhi and Jishan (Shanxi } \\
\text { Province) }\end{array}$ & Fluvo-aquic soil & OM, SR & 6 & 25 & $\begin{array}{l}\text { Wang and Kang } \\
\text { (2009) }\end{array}$ \\
\hline 24 & Changping(Beijing) & Fluvo-aquic soil & $\mathrm{SR}, \mathrm{MF}$ & 8 & 20 & Song et al. (2002) \\
\hline 25 & Hengshui (Hebei Province) & Fluvo-aquic soil & $\begin{array}{l}\text { OM, RNT, } \\
\text { SR, }\end{array}$ & 10 & 15 & Jia et al. (2004) \\
\hline 26 & Qihe (Shandong Province) & Fluvo-aquic soil & OM, SR & 14 & 20 & Lao et al. (2002) \\
\hline 27 & Qihe (Shandong Province) & Fluvo-aquic soil & OM, SR & 15 & 20 & Lao et al. (2003) \\
\hline 28 & Yucheng (Shandong Province) & Fluvo-aquic soil & $\mathrm{OM}, \mathrm{MF}$ & 20 & 20 & Lin et al. (2009) \\
\hline 29 & Luancheng (Hebei Province) & Cinnamon soil & RNT, SR & 5 & 30 & Kong et al. (2010) \\
\hline
\end{tabular}

\subsection{Data Analysis}

Meta-analysis was used to determine the changes in SOC content after adoption the IMPs. In order to conduct the meta-analysis, a suitable effect size indicator which could compare the IMPs treatment mean to CK treatment mean, was calculated as (Osenberg, Sarnelle, Cooper, \& Holt, 1999):

$$
\Delta D_{S O C} y r^{-1}=\frac{\left(D_{S O C t}-D_{S O C 0}\right)-\left(D_{S O C t}^{\prime}-D_{S O C 0}^{\prime}\right)}{t}
$$

Where $\Delta D_{S O C} y r^{-1}$ is the effect size of IPMs on annual SOC sequestration $\left(\mathrm{kg} \mathrm{ha}^{-1} \mathrm{yr}^{-1}\right), D_{S O C t}$ and $D_{\text {SOC } 0}$ are SOC density of final and initial years of each IMPs, $D_{S O C t}^{\prime}$ and $D_{S O C 0}^{\prime}$ are SOC density of final and initial years of CK. The $t$ is the period of each experiment.

As most of the experiments in the selected published articles did not provide some measures of variance for the response variables of SOC content, an unweighted meta analysis was used. After mean effect size for each study was calculated, a bias-corrected $95 \%$ confidence interval (CIs) generated by a bootstrapping procedure using 
MetaWin2.1 software (Rosenberg, Adams, \& Gurevitch, 1997; Johnson \& Curtis, 2001). Means were considered to be significantly different from one another, if their $95 \%$ CIs were non-overlapping and were significantly different from zero if the 95\% CI did not overlap zero (Johnson \& Curtis, 2001; Gurevitch \& Hedges, 1993).

With meta-analysis, we can test whether there are significant differences in mean response among categorical groups. The data from the published literature were also grouped according to their treatment levels except for comparisons of the overall effects of IMPs on SOC sequestration. The treatment levels of OM and MF were both divided into three groups of low $\left(<75 \mathrm{~kg} \mathrm{~N} \mathrm{ha}^{-1} \mathrm{yr}^{-1}\right)$, intermediate $\left(75-150 \mathrm{~kg} \mathrm{~N} \mathrm{ha}^{-1} \mathrm{yr}^{-1}\right)$ and high $(>150 \mathrm{~kg} \mathrm{~N}$ $\left.\mathrm{ha}^{-1} \mathrm{yr}^{-1}\right)$. The treatment levels of SR were also divided into three groups of low $\left(<22.5 \mathrm{~kg} \mathrm{~N} \mathrm{ha}^{-1} \mathrm{yr}^{-1}\right)$,

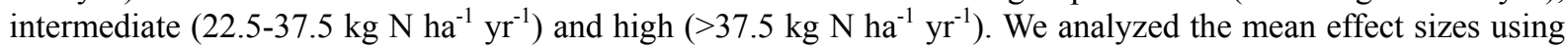
categorical variables which were previously described to examine their effect on SOC sequestration by meta-analysis.

SOC is expected to reach a new equilibrium at some period following adoption a new management practices (Johnson, Levine, \& Kern, 1995). Therefore, we implored the effect duration of IPMs on SOC sequestration based on the data from the selected published literature in this study. The SOC sequestration duration was the time period from the beginning to the ending of SOC increments/decreases induced by different treatments (West \& Six, 2007). Based on the data of the experiments from the selected published literature, we could obtain the average annual change rate of SOC density after IMPs conducting relative to the CK using the following equation (Eq. (4)). By plotting the average annual change rate of SOC density versus the experiment period, we could obtain an estimate of the time required to reach a new SOC steady state from initiating of the experimental IMPs. Nonlinear regression was done to estimate the duration using Sigmaplot 11.0 (Systat Software Incorporated, 2008).

$$
\Delta D_{S O C} y r^{-1} \%=\frac{\left(D_{S O C t}-D_{S O C}\right)-\left(D_{S O C t}^{\prime}-D_{S O C}^{\prime}\right)}{D_{S O C} \times} \times 100 \%
$$

Where $\Delta D_{S O C} y r^{-1} \%$ is the annual change rate of SOC sequestration after IPMs conducting, relative to CK.

\section{Results}

\subsection{Influence of IMPs on SOC Change}

There were 118 paired trials showed positive effects while only 1 trial displayed negative effects in observed long-term experiments. The Bias CIs of OM, MF, SR and RNT were all above zero, indicating a significant effect on SOC sequestration in the topsoil. On average, the IMPs of OM ( $\mathrm{n}=26), \mathrm{MF}(\mathrm{n}=32)$, SR $(\mathrm{n}=44)$ and $(\mathrm{RNT})(\mathrm{n}=17)$ enhanced SOC density by $260,328,278$ and $134 \mathrm{~kg} \mathrm{ha}^{-1} \mathrm{yr}^{-1}$ respectively compared to the CK (Figure 2). The SOC density enhanced by RNT is the lowest among the four IMPs (Figure 2).

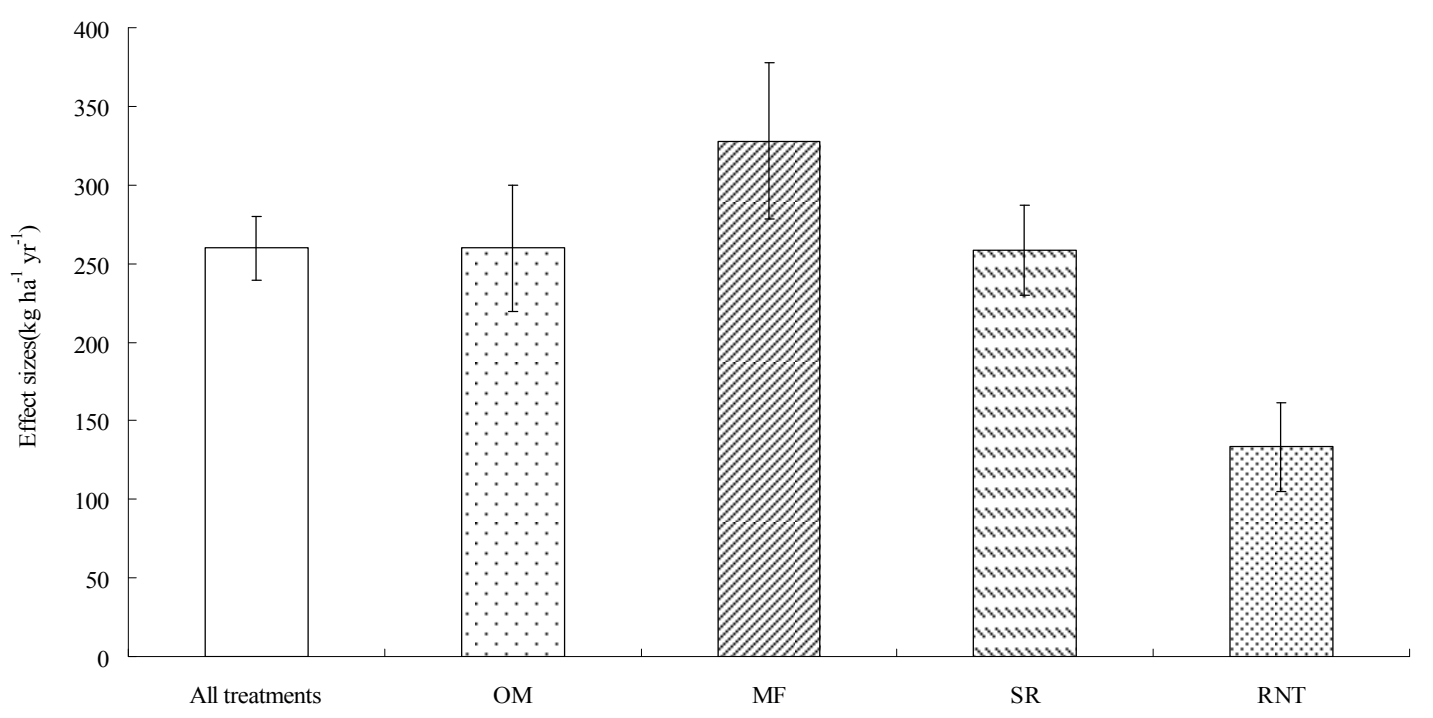

Figure 2. Effect sizes of OM, MF, SR and RNT on SOC sequestration with $95 \%$ bias confidence intervals. The effect size is calculated as Eq. (4) in this study 


\subsection{Effects of Treatment Level on SOC Sequestration}

The amounts of OM, MF and SR affirmatively affected the effect size on SOC sequestration (Figure. 3, P $<0.05$ ). The effect size of OM for the high level group (339 $\left.\mathrm{kg} \mathrm{ha}^{-1} \mathrm{yr}^{-1}, \mathrm{n}=7\right)$ was greater than that of the intermediate level of application $\left(289 \mathrm{~kg} \mathrm{ha}^{-1} \mathrm{yr}^{-1}, \mathrm{n}=9\right)$ and the low level group as well $\left(164 \mathrm{~kg} \mathrm{ha}^{-1} \mathrm{yr}^{-1}, \mathrm{n}=10\right)$, but no significant difference $(\mathrm{P}=0.16)$ was detected between them. Similar trends were found in the treatments using variable amounts of MF. SOC sequestration in the high level group of OM $(\mathrm{n}=13)$ was $509 \mathrm{~kg} \mathrm{ha}^{-1} \mathrm{yr}^{-1}$ higher than that of the intermediate level of application $\left(243 \mathrm{~kg} \mathrm{ha}^{-1} \mathrm{yr}^{-1}, \mathrm{n}=9\right)$ and the low level group as well $(170 \mathrm{~kg}$ $\left.\mathrm{ha}^{-1} \mathrm{yr}^{-1}, \mathrm{n}=10\right)$, there were significant difference between high level group and low level group $(\mathrm{P}=0.002)$, intermediate level group and low level group $(\mathrm{P}=0.017)$, but no significant difference was detected between high level group and intermediate level group $(\mathrm{P}=0.522)$. Similar trends were also found in the treatments using variable amounts of SR. SOC sequestration in the high level group of OM $(\mathrm{n}=19)$ was $339 \mathrm{~kg} \mathrm{ha}^{-1} \mathrm{yr}^{-1}$ higher than that of the intermediate level of application $\left(251 \mathrm{~kg} \mathrm{ha}^{-1} \mathrm{yr}^{-1}, \mathrm{n}=13\right)$ and the low level group as well (166 $\left.\mathrm{kg} \mathrm{ha}^{-1} \mathrm{yr}^{-1}, \mathrm{n}=12\right)$, there were only significant difference between high level group and low level group ( $\mathrm{P}=$ $0.011)$.

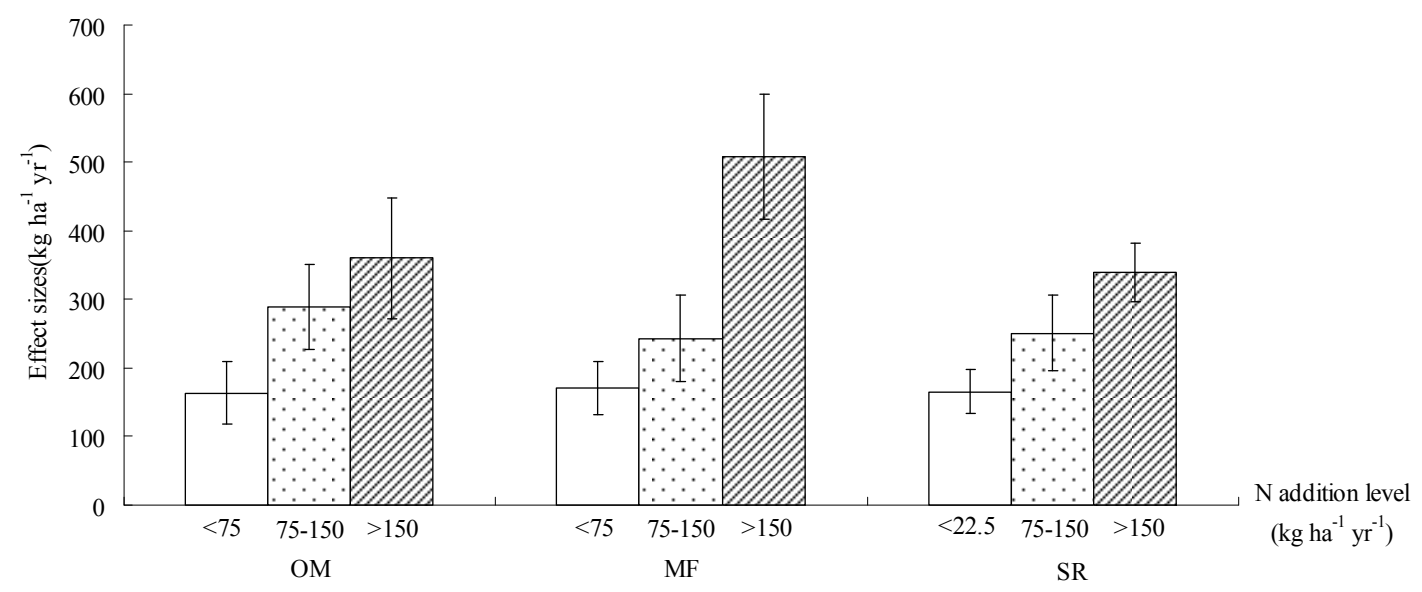

Figure 3. Differences in effect sizes of OM, MF and SR on SOC sequestration between treatment levels with $95 \%$ bias confidence intervals. The effect size is calculated as Eq. (4) in this study

\subsection{Effect Duration of IMPs on SOC Sequestration}

The annual change rate of SOC sequestration induced by OM, MF, SR and RNT in wheat-maize double cropping system in north China showed that the duration of SOC sequestration differed significantly. The correlation between $\Delta D_{S O C} y r^{-1} \%$ and $t$ for these four treatments, using a traditional nonlinear regression analysis, were obtained using the following equations of (5), (6), (7) and (8), respectively.

$$
\begin{aligned}
& \Delta D_{S O C} y r^{-1} \%=\frac{10.0340}{t}-0.2093, \quad\left(n=26, R^{2}=0.5790^{* *}\right) \\
& \Delta D_{S O C} y r^{-1} \%=\frac{12.7737}{t}-0.5157, \quad\left(n=32, R^{2}=0.6130^{* *}\right) \\
& \Delta D_{S O C} y r^{-1} \%=\frac{8.2090}{t}-0.3781, \quad\left(n=44, R^{2}=0.4460^{* *}\right) \\
& \Delta D_{S O C} y r^{-1} \%=\frac{5.1100}{t}-0.2872, \quad\left(n=17, R^{2}=0.2430^{*}\right)
\end{aligned}
$$

Seen from Figure 4, the SOC sequestration rates were normally high in the early stage of the four IMPs, and then decreased with consequent increases of SOC pool and finally became zero as SOC reached a new equilibrium level. During the first 10 years, the decreased rate of SR was most quickly among them. According to the calculation with the four equations, the effect durations of OM (Figure 4a), MF (Figure 4b), SR (Figure 4c) and RNT (Figure 4d) on SOC sequestration were about 48, 26, 22 and 18 years, respectively. Accumulation enhancement of SOC for IMPs over SOC sequestration period can be seen (Figure 4), if the differences were considered in duration in this study. We can conclude that the multiplication factors of 1.35, 1.36, 1.22 and 1.13, 
corresponding to $34.7 \%, 36.1 \%, 22.0 \%$ and $12.7 \%$ increase in SOC, could be recommended ultimately for a change to OM, MF, SR and RNT in the study area, respectively.
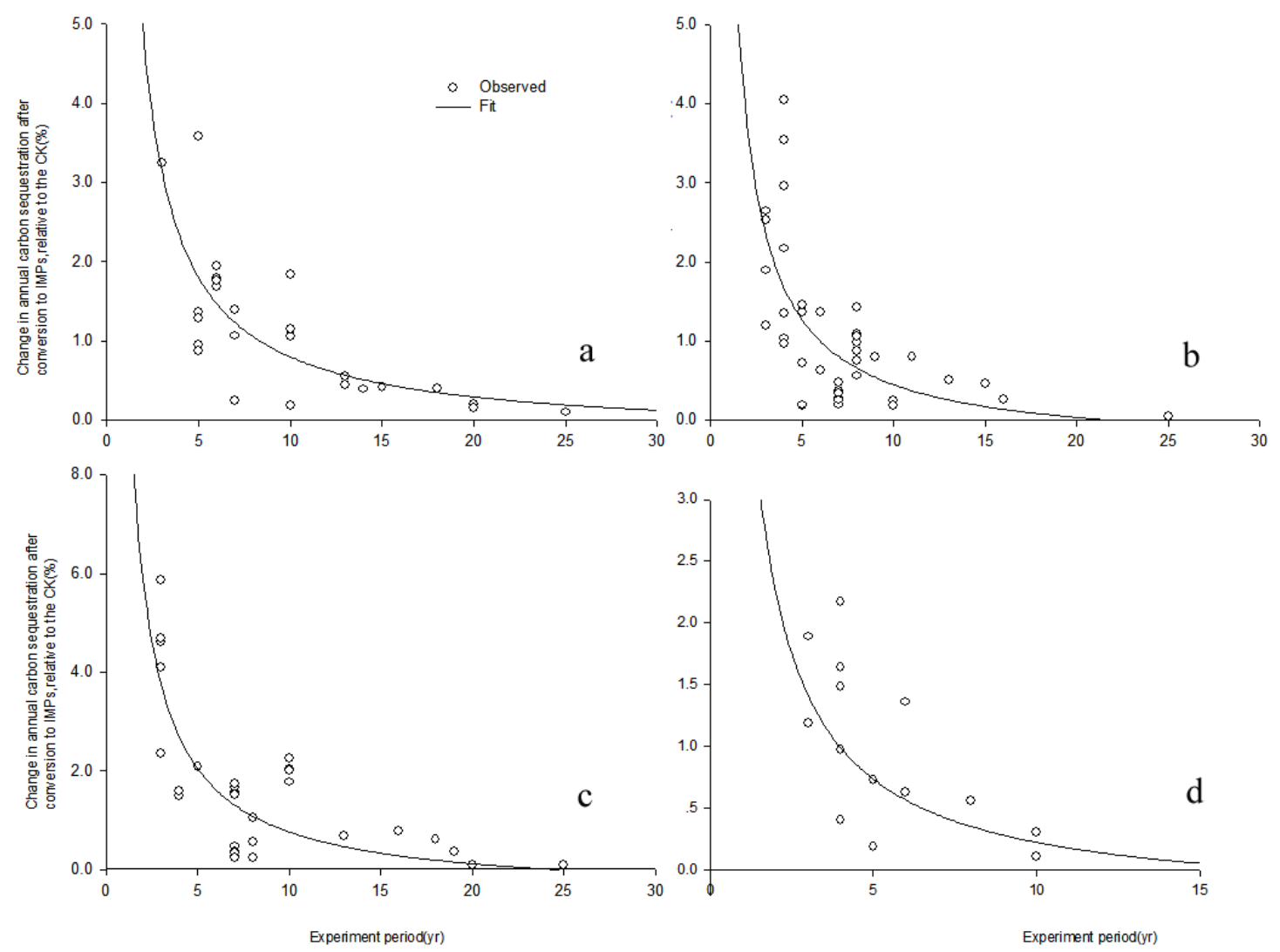

Figure 4. Duration of SOC sequestration of (a) OM, (b) SR,(c) MF and (d) RNT; the CK means the control check of (a) OM, (b) SR,(c) MF and (d) RNT, respectively

\section{Discussion}

\subsection{Effect Size of IMPs on SOC Sequestration}

The results presented here indicate that the four IMPs all have considerable SOC sequestration potentials in wheat-maize double cropping system in north China. FM can sequester SOC at an average of $328 \mathrm{~kg} \mathrm{ha}^{-1} \mathrm{yr}^{-1}$ in study area, which was lower than that of $573 \mathrm{~kg} \mathrm{ha}^{-1} \mathrm{yr}^{-1}$ in soybean-wheat double cropping system in Indian concluded by Kundu et al (Kundu, Ranjan, Ved, Ghosh, \& Gupta, 2007). Among the four IMPs, FM has the best SOC sequestration effect. The reason would be that addition manure to fertilizer could promote formation of micro-aggregates in the macro-aggregates, leading to more particulate organic matter fixed in the newly formed micro-aggregates (Six, Ekkuitt, \& Paustian, 1999). Moreover, comparing with the large aggregates, soil micro-aggregates have lower turnover rate and higher stability (Jastrow, Boutton, \& Miller, 1996; Balesdent, Chen, \& Balabane, 2000). OM can increase the input of SOC, and accelerate SOC accumulation in the soil (Chen, Wang, \& Wang, 2008). In the study area, OM can sequester SOC an average of $260 \mathrm{~kg} \mathrm{ha}^{-1} \mathrm{yr}^{-1}$, which was higher than that of $150 \mathrm{~kg} \mathrm{ha}^{-1} \mathrm{yr}^{-1}$ in Europe cropland concluded by Vleeshouwers and Verhagen (Vleeshouwers \& Verhagen, 2002), lower than that of previous researchers with an effect of $390 \mathrm{~kg} \mathrm{ha}^{-1} \mathrm{yr}^{-1} \mathrm{of}^{-1}$ USA cropland estimated by Jarecki et al (Jarecki, Lai, \& James, 2005), $350 \mathrm{~kg} \mathrm{ha}^{-1} \mathrm{yr}^{-1}$ of Belgium cropland evaluated by Dendoncker et al. and $510 \mathrm{~kg} \mathrm{ha}^{-1} \mathrm{yr}^{-1}$ in southeastern USA estimated by Upendra et al ( Upendra et al., 2008; Dendoncker, Wesemael, \& Rounsevell, 2004). SR achieves SOC sequestration through increasing the carbon input to the soil. Lal and $\mathrm{Lu}$ et al. reported that about $8.0-35.7 \%$ of the organic $\mathrm{C}$ in straw were preserved in the form of SOC in the soil (Lal, 2007; Lu, Wang, Han, Ouyang, \& Zhen, 2009). In the study area, straw return to field can significantly increase $C$ content with an average effect of $278 \mathrm{~kg} \mathrm{ha}^{-1} \mathrm{yr}^{-1}$ in cropland soil compared to CK, which was lower than the effect of $410 \mathrm{~kg} \mathrm{ha}^{-1} \mathrm{yr}^{-1}$ in Yangtze Delta plain of China reported by Rui and Zhang (2010), significantly higher than the effect of $150 \mathrm{~kg} \mathrm{ha}^{-1} \mathrm{yr}^{-1}$ in Europe suggested by 
Vleeshouwers and Verhagen and $20 \mathrm{~kg} \mathrm{ha}^{-1} \mathrm{yr}^{-1}$ in Europe estimated by Smith (Smith, 2004b). The discrepancies could be due to difference in climate and soil conditions(Yan et al., 2007; Angers, 1997; Gregorich et al., 2000). RNT can reduce soil C release by reducing the turnover of soil aggregates (Paustian, Elliott, Six, \& Hunt, 2000), which has been taken as an effective and environmentally friendly soil C sequestration strategy (Lal, 2004). Soil C sequestration rates, with a change to RNT from CT in study area, can be expected to $134 \mathrm{~kg} \mathrm{ha}^{-1} \mathrm{yr}^{-1}$, which was within the higher range of values (approximately 100-600 $\mathrm{kg} \mathrm{ha}^{-1} \mathrm{yr}^{-1}$ ) cited by Follett (2001). The value was lower than that of $420 \mathrm{~kg} \mathrm{ha}^{-1} \mathrm{yr}^{-1}$ in southeastern USA estimated by Franzluebbers (2005) and $570 \mathrm{~kg} \mathrm{ha}^{-1}$ $\mathrm{yr}^{-1}$ at a global scale estimated by West and Post (2002). The result was also significantly higher than that of 30 $\mathrm{kg} \mathrm{ha}^{-1} \mathrm{yr}^{-1}$ in paddy field in Yangtze Delta plain of China reported by Rui and Zhang (2010), which was consistent with the viewpoint proposed by Han et al. who reported that the great carbon sequestration potential under no tillage only existed in dryland soils in China (Han, Wang, Lu, Duan, \& Ouyang, 2008).

Though the four IMPs can significantly enhance SOC of cropland, the negative effects of inducing greenhouse gas emissions have to be considered when judging them. Li et al. found that reduced tillage, crop residue incorporation and manure application each would increase $\mathrm{N}_{2} \mathrm{O}$ emissions in arable soils ( $\mathrm{Li}$, Frolking, \& Butterbach, 2005). Gregorich also estimated that the amount of $\mathrm{N}_{2} \mathrm{O}$ emission caused by manure application accounted for about $10 \%$ of the total $\mathrm{N}_{2} \mathrm{O}$ emission in cropland in Canada (Gregorich et al., 2000). Therefore, managements and policies to sequester $\mathrm{C}$ in soils are needed to have a discreet and comprehensive consideration. Further attentions should be paid to the quantitatively assessment of the net global warming potential induced by IMPs in wheat-maize double cropping system in north China.

\subsection{Duration of SOC Sequestration}

SOC sequestration is not infinite but will get to a saturation status after decades with implementation of IMPs (Watson et al., 2000). C sequestration duration is synonymous with the time to which soil C steady state is reached (West \& Six, 2007). Seen from this study, the SOC sequestration duration of OM, MF, SR and RNT were about 48, 26, 22 and 18 years, respectively. The duration of OM on SOC sequestration was the longest among these four IMPs. This time period was longer than the pervious estimates of 40 years (Rui \& Zhang, 2010), and was within that of 60 years estimated by Chen et al (Chen et al., 2004). SOC sequestration duration of MF in our study was shorter than OM, and longer than SR and RNT. The SOC sequestration duration of SR in our study was similar to that of 20 years suggested by IPCC (2006), and was consistent with those used in modeling estimations by Yan et al. The duration of RNT on SOC sequestration was the shortest with that of 18 years among the four IPMs in this study, which was within the duration value of 60 years estimated by Yan et al. Meanwhile, the value coincided with that suggested by West and Post (2002)' who concluded that duration of 20 years was optimum for a change from CT to NT.

These results provide us with the basic information that there is a large SOC uptake potential in wheat-maize double cropping system in north China. It is also useful to make climate policy and land management strategies by the virtue of the duration of SOC uptake potential under different IMPs. The consistencies showed that the SOC duration summarized in this research can be used as an index to assess the SOC sequestration potential of the four IMPs in wheat-maize double cropping system in north China. Furthermore, from the multiplication factors determined by us for a change to OM, MF, SR and RNT in this study area, we can conclude that OM and MF could be the appropriate practices on SOC sequestration in wheat-maize double cropping system in north China.

\section{Conclusions}

Results of this study showed that OM, MF, SR and RNT all have significant effects on SOC sequestration of wheat-maize double cropping system in north China, and the effect size of RNT was the lowest among them. The amounts of OM, MF and SR affirmatively affected the effect size on SOC sequestration, and the effect sizes of them for the high level group were all greater than those of the intermediate level of application and the low level group as well. The effect durations of the four IMPs on SOC sequestration were about 48, 26, 22 and 18 years, respectively. The duration of OM was significantly longer than that of other three IMPs. The multiplication factors of $1.35,1.36,1.22$ and 1.13 could be used for a change to OM, MF, SR and RNT in this study area, respectively. OM and MF were the appropriate practices on SOC sequestration in wheat-maize double cropping system in north China.

\section{Acknowledgements}

This work was supported by the Special Fund for Agro-scientific Research in the Public Interest (No.201103001). We would like to thank the two anonymous reviewers for their insightful comments and suggestions on this manuscript. 


\section{References}

Adams, W. A. (1973). The effects of organic matter on the bulk and true densities of some uncultivated podzolic soils. J. Soil Sci., 24, 10-17. http://dx.doi.org/10.1111/j.1365-2389.1973.tb00737.x

Álvaro-Fuentes, J., López, M. V., Cantero-Martinez, C., \& Arrúe, J. L. (2008). Tillage effects on in Mediterranean soil organic carbon fractions dryland agro-ecosystems. Soil Sci. Soc. Am. J., 72, 541-547. http://dx.doi.org/10.2136/sssaj2007.0164

Angers, D. A., Bolinder, M. A., Carter, M. R., Gregorich, E. G., Drury, C. F., Liang, B. C., ... Martel, J. (1997). Impact of tillage practices on organic carbon and nitrogen storage in cool, humid soils of eastern Canada. Soil Tillage Res., 41, 191-201. http://dx.doi.org/10.1016/S0167-1987(96)01100-2

Balesdent, J., Chen, N. C., \& Balabane, M. (2000). Relationship of soil organic matter dynamics to physical protection and tillate. Soil Tillage Res., 53, 215-230. http://dx.doi.org/10.1016/S0167-1987(99)00107-5

Chen, Y., Wang, S. J., Wu, C. Y., Wang, Z. X., Zhang, L. J., Zhang, L. L., ... Zhang, F. D. (2004). Study on the balance and mathematical modeling of organic carbon in the soils of paddy field. Acta Agr. Zhejiangensis., 16(1), 1-6.

Chen, G. P., Wei, D. M., \& Yang, H. Y. (1992). Discuss on new multiple cropping of wheat-maize in north China. Crops., 1, 20.

Chen, P. Q., Wang, X. K., \& Wang, L. M. (2008). Carbon budget and its sink promotion of terrestrial ecosystem in China. Beijing: Science Press, China.

Christopher, S. F., Lal, R., \& Mishra, U. (2009). Regional study of no-till effects on carbon sequestration in Midwestern United States. Soil Sci. Soc. Am. J., 73, 207-216. http://dx.doi.org/10.2136/sssaj2007.0336

Dendoncker, N., Wesemael, B. V., \& Rounsevell, M. D. A. (2004). Belgium's $\mathrm{CO}_{2}$ mitigation potential under improved cropland management. Agric. Ecosyst. Enviro., 103, 101-116. http://dx.doi.org/10.1016/j.agee.2003.10.010

Dong, L. H., Li, Y. Y., Pang, H. C., \& Sun, Q. Q. (2010). Comparison of the effect of long-term fertilizer application on soil nutrients and wheat yield under different soil types. J. China Agric. U., 15, 22-28 (in Chinese).

Editorial Board of China Agriculture Yearbook. (2009). China Agriculture Yearbook 2009, Electronic Edition. China Agriculture Press, Beijing, China.

Fedorov, S. (2002). Get Data Graph Digitizer Version 2.23. Get data-graph-digitizer-com, Russia.

Follett, R. F. (1993). Global climatic change, U.S. agriculture and carbon dioxide. J. Prod. Agric., 6, 181-190.

Follett, R. F. (2001). Soil management concepts and carbon sequestration in cropland soils. Soil Tillage Res., 61, 77-92. http://dx.doi.org/10.1016/S0167-1987(01)00180-5

Franzluebbers, A. J. (2005). Soil organic carbon sequestration and agricultural greenhouse gas emissions in the southeastern USA. Soil Tillage Res., 83, 120-147. http://dx.doi.org/10.1016/j.still.2005.02.012

Gong, W., Yan, X. Y., Cai, Z. C., Wang, J. Y., Hu, T. X., Gong, Y. B., \& Ran, H. (2008). Effects of long-term fertilization on soil particulate organic carbon and nitrogen in a wheat-maize cropping system. Chin. J. Appl. Ecol., 19, 2375-2381.

Gregorich, E. G., Rochette, P., VandenBygaart, A. J., \& Angers, A. D. (2005). Greenhouse gas contributions of agricultural soils and potential mitigation practices in Eastern Canada. Soil Tillage Res., 83, 53-72. http://dx.doi.org/10.1016/j.still.2005.02.009

Gu, B. X., Zhao, Z. Q., Wang, Z. W., Jia, S. L., Zhang, Y. C., \& Li, X. H. (1992). Study on the influence of organic material on soil organic matter quality and production of salinization Alluvial soil. Chin. J. Soil Sci., $23,28-30$.

Gurevitch, J., \& Hedges, L. V. (1993). Meta-analysis: combining the results of independent experiments. In: Scheiner, S.M., Gurevitch, J. (Eds.), Design and Analysis of Ecological Experiments. Chapman and Hall, New York, USA, pp. 378-398.

Han, B., Kong, F. R., Zhang, H. L., \& Chen, F. (2010). Effects of tillage conversion on carbon sequestration capability of farm land soil doubled cropped with wheat and corn. Chin. J. Appl. Ecol., 21, 91-98 (in Chinese). 
Han, B., Wang, X. K., Lu, F., Duan, X. N., \& Ouyang, Z. Y. (2008). Soil carbon sequestration and its potential by cropland ecosystems in China. Acta Ecol. Sin., 28, 612-619 (in Chinese).

Han, Z. Q., Zhang, D. X., Chen, H. B., Chang, L. S., Yu, Y. Q., Liu, D. Q., \& Wang, J. Y. (2003). The evolvement rule of soil's organic matter quality under the condition of long-term and oriented fertilization of wheat-corn rotation system. J. Hebei Vocation-Tech. Teach. Coll., 17, 10-14 (in Chinese).

Havlin, J. L., Kissel, D. E., Maddux, L. D., Claassen, M. M., \& Long, J. H. (1990). Crop rotation and tillage effects on soil organic carbon and nitrogen. Soil Sci. Soc. Am. J., 54, 448-452. http://dx.doi.org/10.2136/sssaj1990.03615995005400020026x

Hechtel, L. J., \& Juliano, S. A. (1997). Effects of a predator on prey metamorphosis: plastic responses by prey or selective mortality? Ecology, 928-851. http://dx.doi.org/10.1890/0012-9658(1997)078[0838:EOAPOP]2.0.CO;2

Hermle, S., Anken, T., Leifeld, J., \& Weisskopf, P. (2008). The effect of the tillage system on soil organic carbon content under moist, cold-temperate conditions. Soil Tillage Res., 98, 94-105. http://dx.doi.org/10.1016/j.still.2007.10.010

Huang, B. F. (1984). Studies on effect of turnover of green-manure and wheat straw into soil fertility-I. Effect of green-manure and wheat straw on characteristics of aggregates and organic matter in soil. Acta Pedol. Sin., 21, 113-122 .

IPCC. (2006). 2006 IPCC Guidelines for National Greenhouse Gas Inventories. NGGIP, IGES, Kanagawa, Japan.

IPCC. (2007). Climate Change 2007: Mitigation of Climate Change of Working Groups III to the Fourth Assessment Report of the Intergovernmental Panel on Climate Change. Cambridge University Press, Cambridge, UK.

Jarecki, M. K., Lai, R., \& James, R. (2005). Crop management effects on soil carbon sequestration on selected farmers' fields in northeastern Ohio. Soil Tillage Res., 81, 265-276. http://dx.doi.org/10.1016/j.still.2004.09.013

Jastrow, J. D., Boutton, T. W., \& Miller, R. M. (1996). Carbon dynamics of aggregate-associated organic matter estimated by ${ }^{13} \mathrm{C}$ natural abundance. Soil Sci. Soc. Am. J., 60, 801-807. http://dx.doi.org/10.2136/sssaj1996.03615995006000030017x

Jia, S. L., Meng, C. X., Ren, T. S., \& Yang, Y. M. (2004). Effect of tillage and residue management on crop yield and soil properties. J. Hebei Agric. Sci., 8, 37-42 (in Chinese).

Jin, W. X., Wang, X. P., Yu, Y. N., Zeng, M. X., \& Zhao, X. Y. (1983). Effect of organic combined with chemical fertilizer application on crop yield and soil. Chin. J. Soil Sci., 5, 9-11 (in Chinese).

John, T. S., Marcus, M. A., Ronald, F. F., \& James, V. W. (2008). Soil carbon sequestration with continuous no-till management of grain cropping systems in the virginia coastal plain. Soil Tillage Res., 100, 133-140. http://dx.doi.org/10.1016/j.still.2008.05.010

Johnson, D. W., \& Curtis, P. S. (2001). Effects of forest management on soil C and N storage: meta analysis. For. Ecol. Manage., 140, 227-238. http://dx.doi.org/10.1016/S0378-1127(00)00282-6

Johnson, M. G., Levine, E. T., \& Kern, J. S. (1995). Soil organic matter distribution, genesis, and management to reduce greenhouse gas emissions. Water Air Soil Pollut., 82, 593-615. http://dx.doi.org/10.1007/BF00479414

Kong, F. L., Zhang, H. L., Sun, G. F., Huang, G. H., \& Chen, F. (2010). Rotational tillage effects on characteristics of soil carbon pool for the wheat-corn system. J. Soil Water Conserv., 24, 150-154.

Kou, C. L., Wang, Q. J., Wang, Y. Q., Wu, J. C., \& Wang, H. Y. (2000). Effect of fertilizing structure on the change of organic matter and N, P and $\mathrm{K}$ nutrients in sand soil. Eco-Agric. Res., 8, 47-51.

Kundu, S., Ranjan, B., Ved, P., Ghosh, B. N., \& Gupta, H. S. (2007). Carbon sequestration and relationship between carbon addition and storage under rained soybean-wheat rotation in a sandy loam soil of the Indian Himalayas. Soil Tillage Res., 92, 87-95. http://dx.doi.org/10.1016/j.still.2006.01.009

Lal, R. (2004). Soil carbon sequestration impacts on global climate change and food security. Science, 304, 1623-1627. http://dx.doi.org/10.1126/science. 1097396

Lal, R. (2007). Carbon management in agricultural soils. Mitigation and Adaptation Strategies for Global 
Change, 12, 303-322.http://dx.doi.org/10.1007/s11027-006-9036-7

Lal, R., Follett, R. F., Kimble, J., \& Cole, C. V. (1999). Managing U.S. cropland to sequester carbon in soil. J. Soil Water Cons., 54, 374-381.

Lao, X. R., Sun, W. H., Wang, Z., Hao, Y. R., \& Zhang, C. A. (2003). Effect of matching use of straw and chemical fertilizer on soil fertility. Acta Pedol. Sin., 40, 618-623.

Lao, X. R., Wu, Z. Y., \& Gao, Y. C. (2002). Effect of long-term returning straw to soil on soil fertility. T. CSAE., $18,49-52$.

Li, C., Frolking, S., \& Butterbach, B. K. (2005). Carbon sequestration in arable soils is likely to increase nitrous oxide emissions, offsetting reductions in climate radiative forcing. Clim. Change., 72, 321-338. $\mathrm{http}: / / \mathrm{dx}$. doi.org/10.1007/s10584-005-6791-5

Li, K. J., Ma, J. Y., Cao, C. Y., Zheng, C. L., \& Sun, W. F. (2007). Effect of the long-term different organic fertilizer applications on crop yield and soil properties. J. Hebei Agric. Sci., 11, 60-63.

Li, L., Li, S. J., Zhang, H. L., \& Chen, F. (2006). Study on soil C pool management index of conversation tillage. J. Soil Water Conserv., 20, 106-109.

Li, S. D., Wang, F. H., Si, J. S., Kong, L. A., Liu, J. J., Feng, B., \& Zhang, B. (2009). Effect of different farming methods on soil microbial biomass and soil fertility. Ecol. Environ. Sci., 18, 1961-1964.

Lin, Z. A., Zhao, B. Q., Yuan, L., \& Hwat, B. S. (2009). Effects of organic manure and fertilizers long-term located application on soil fertility and crop yield. Sci. Agric. Sin., 42, 2809-2819.

Liu, C. M., Zhang, G. L., Zhang, Z. W., \& Bao, D. J. (1993). Fertilizer location experiment of one-year wheat-corn rotation. Acta Agric. Boreali-Sin., 8, 127-132.

Liu, E. K., Mei, X. R., Zhao, B. Q., Li, X. Y., Liu, J. J., \& Hu, Q. H. (2009). The Effects of long-term fertilization on soil microbial biomass of carbon, nitrogen and phosphorus. J. China Agric. U., 14, 63-68.

Lu, F., Wang, X. K., Han, B., Ouyang, Z. Y., \& Zhen, H. (2009). Soil carbon sequestrations by nitrogen fertilizer application, straw return and no-tillage in China's cropland. Global Change Biol., 15, 281-305. http://dx.doi.org/10.1111/j.1365-2486.2008.01743.x

Luo, Z. K., Wang, E. L., \& Sun, O. J. (2010). Can no-till stimulate carbon sequestration in agricultural soil? A meta-analysis of paired experiments. Agric. Ecosyst. Environ., 139, 224-231. http://dx.doi.org/10.1016/j.agee.2010.08.006

Ma, Y. L., Shi, H. K., Zhang, S. K., \& Lv, R. H. (2003). Whole maize straw addition: the change s of soil physical and chemical properties and the effect on winter wheat. J. China Agric. U., 8, $42-46$.

Meng, L., Ding, W. X., Cai, Z. C., \& Qin, S. W. (2005). Storage of soil organic and soil respiration as effected by long-term quantitative fertilization. Adv. N Earth Sci., 20, 687-692.

Morari, F., Lugato, E., Berti, A., \& Giardini, L. (2006). Long-term effects of recommended management practices on soil carbon changes and sequestration in north-eastern Italy. Soil Use Manage., 22, 71-78. http://dx.doi.org/10.1111/j.1475-2743.2005.00006.x

Nelson, D. E., \& Sommers, L. E. (1982). Total carbon, organic carbon, and organic matter. In: Page, A.L., Miller, R. H., Keeney, D. R. (Eds.), Methods of Soil Analyses. Part 2. Chemical and Microbiological Properties. 2nd ed. American Society of Agronomy, Wisconsin.

Niu, L. A., Hao, J. M., Zhao, B. Z., Niu, X. S., \& Lv, Z. Y. (2009). Soil respiration and carbon balance in farmland ecosystems on North China Plains. Ecol. Environ. Sci., 18, 1054-1060.

Osenberg, C. W., Sarnelle, O., Cooper, S. D., \& Holt, R. D. (1999). Resolving ecological questions through meta-analysis: goals, metrics, and models. Ecology, 80, 1105-1117. http://dx.doi.org/10.1890/0012-9658(1999)080[1105:REQTMA]2.0.CO;2

Paustian, K., Elliott, E. T., Six, J., \& Hunt, H. W. (2000). Management options for reducing $\mathrm{CO}_{2}$ emissions from agricultural soils. Biogeochemistry, 48, 147-163. http://dx.doi.org/10.1023/A:1006271331703

Qin, S. W., Gu, Y. C., \& Zhu, Z. L. (1998). A preliminary report on long-term stationary experiment on fertility evolution of fluvo-aquic soil and the effect of fertilization. Acta Pedol. Sin., 35, 367-375 (in Chinese).

Rosenberg, M. S., Adams, D. C., \& Gurevitch, J. (1997). MetaWin: Statistical Software for Meta-analysis with Resampling Tests. Sinauer Associates, Sunderland, MA, USA. 
Rui, W. Y., \& Zhang, W. J. (2010). Effect size and duration of recommended management practices on carbon sequestration in paddy field in Yangtze Delta Plain of China: a meta-analysis. Agric. Ecosyst. Environ., 135, 199-205. http://dx.doi.org/10.1016/j.agee.2009.09.010

Six, J., Ekkuitt, E. T., \& Paustian, K. (1999). Aggregate and soil organic matter dynamics under conventional and no-tillage systems. Soil Sci. Soc. Am. J., 63, 1350-1358. http://dx.doi.org/10.2136/sssaj1999.6351350x

Smith, P. (2004a). Soils as carbon sinks: the global context. Soil Use Manage., 20, 212-218. http://dx.doi.org/10.1079/SUM2004233

Smith, P. (2004b). Carbon sequestration in croplands: the potential in Europe and the global context. Eur. J. Agron., 20, 229-236. http://dx.doi.org/10.1016/j.eja.2003.08.002

Smith, P., Powlson, D. S., Glendining., M. J., \& Smith, J. U. (1998). Preliminary estimates of the potential for carbon mitigation in European soils through no-till farming. Global Change Boil., 4, 679-685. http://dx.doi.org/10.1046/j.1365-2486.1998.00185.x

Song, Y. L., Tang, H. J., \& Li, X. P. (2007). The Effects of long-term fertilization on crop yield and aqui-cinnamon soil organic matter. Acta Agric. Boreali-Sin., 22, 100-105.

Song, Y. L., Yuan, F. M., \& Yao, Z. H. (2002). Effect of combination of NPK chemical fertilizer and different organic materials on crop yield and soil organic matter. Acta Agric. Boreali - Sin., 17, 73-76.

Systat Software Incorporated. (2008). Sigmaplot 11.0. Systat Software Incorporated, Point Richmond, California, USA.

Tian, S. Z., Ning, T. Y., Wang, Y., Li, H. J., Zhong, W. L., \& Li, Z. J. (2010). Effects of different tillage methods and straw-returning on soil organic carbon con ten $\mathrm{t}$ in a winter wheat field. Chin. J. Appl. Ecol., 21, 373-378.

Upendra, M. S., Zachary, N. S., Ermson, Z. N., Irenus, A. T., \& Reddy K. C. (2008). Soil carbon and nitrogen sequestration as affected by long-term tillage, cropping systems, and nitrogen fertilizer sources. Agric. Ecosyst. Environ., 127, 234-240. http://dx.doi.org/10.1016/j.agee.2008.04.006

Uri, N. D. (2001). Conservation practices in US agriculture and their impact on carbon sequestration. Environ. Monit. Assess., 70, 323-344. http://dx.doi.org/10.1023/A:1010735510641

Vleeshouwers, L.M., \& Verhagen, A. (2002). Carbon emission and sequestration by agricultural land use: a model study for Europe. Global Change Biol., 8, 519-530. http://dx.doi.org/10.1046/j.1365-2486.2002.00485.x

Wang, H. J., \& Kang, X. D. (2009). Effect of stalk mulch to soil organic matter level. J. Shanxi Agric. Sci., 37, $42-45$.

Wang, X. B., Cai, D. X., Zhang, J. Q., \& Gao, X. K. (2000). Effects of corn stover incorporated in dry farmland on soil fertility. Sci. Agric. Sin., 33, 54-61.

Wang, X. L., Chen, M. C., \& Zhang, L. (2007). Effect of different tillage ways on soil microbial biomass and soil enzyme activities. Anhui Agric. Sci. Bull., 13, 28-30.

Watson, R. T., Noble, I. R., Bolin, B., Ravindranath, N. H., Verardo, D. J., \& Dokken, D. J. (2000). Land Use, Land Use Change, and Forestry. Cambridge University Press, Cambridge, UK.

West, T. O., \& Post, W. M. (2002). Soil organic carbon sequestration rates by tillage and crop rotation: a global data analysis. Soil Sci. Soc. Am. J., 66, 1930-1946. http://dx.doi.org/10.2136/sssaj2002.1930

West, T. O., \& Six, J. (2007). Considering the influence of sequestration duration and carbon saturation on estimates of soil carbon capacity. Clim. Change, 80, 25-41.http://dx.doi.org/10.1007/s10584-006-9173-8

Xing, S. L., Han, B. W., Liu, M. C., \& Xu, M. G. (2010). Effect of combination of NPK chemical fertilizer and different organic materials on soil nutrient and yield stability of wheat. J. Agro-Environ. Sci., 29, 135-140.

Yan, H. M., Cao, M. K., Liu, J. Y., \& Tao, B. (2007). Potential and sustainability for carbon sequestration with improved soil management in agricultural soils of China. Agric. Ecosyst. Environ., 121, 325-335. http://dx.doi.org/10.1016/j.agee.2006.11.008

Zhao, R. F., Chen, X. P., \& Zhang, F. S. (2009). Nitrogen cycling and balance in winter-wheat-summer-maize rotation system in northern china plain. Acta Pedol. Sin., 46, 684-697.

Zhu, H. X., Zhang, X., Li, G. B., \& Sun, C. H. (1996). Effect of fertilization on soil fertility and yield increasing of wheat and maize. Soil Fertil., 5, 23-26 . 